\author{
Case Study
}

\title{
EFFECTIVENESS OF MULTIMODAL AYURVEDIC TREATMENT IN VATAJA PANDU W.S.R NUTRITIONAL DEFICIENCY ANEMIA - A CASE REPORT
}

\section{Swathi Bhat ${ }^{*}$, Ananta $S$ Desai ${ }^{2}$ \\ *1PG Scholar, ${ }^{2}$ Professor and Head, Department of Post Graduate Studies in Panchakarma, Government Ayurveda Medical College, Bengaluru, Karnataka, India.}

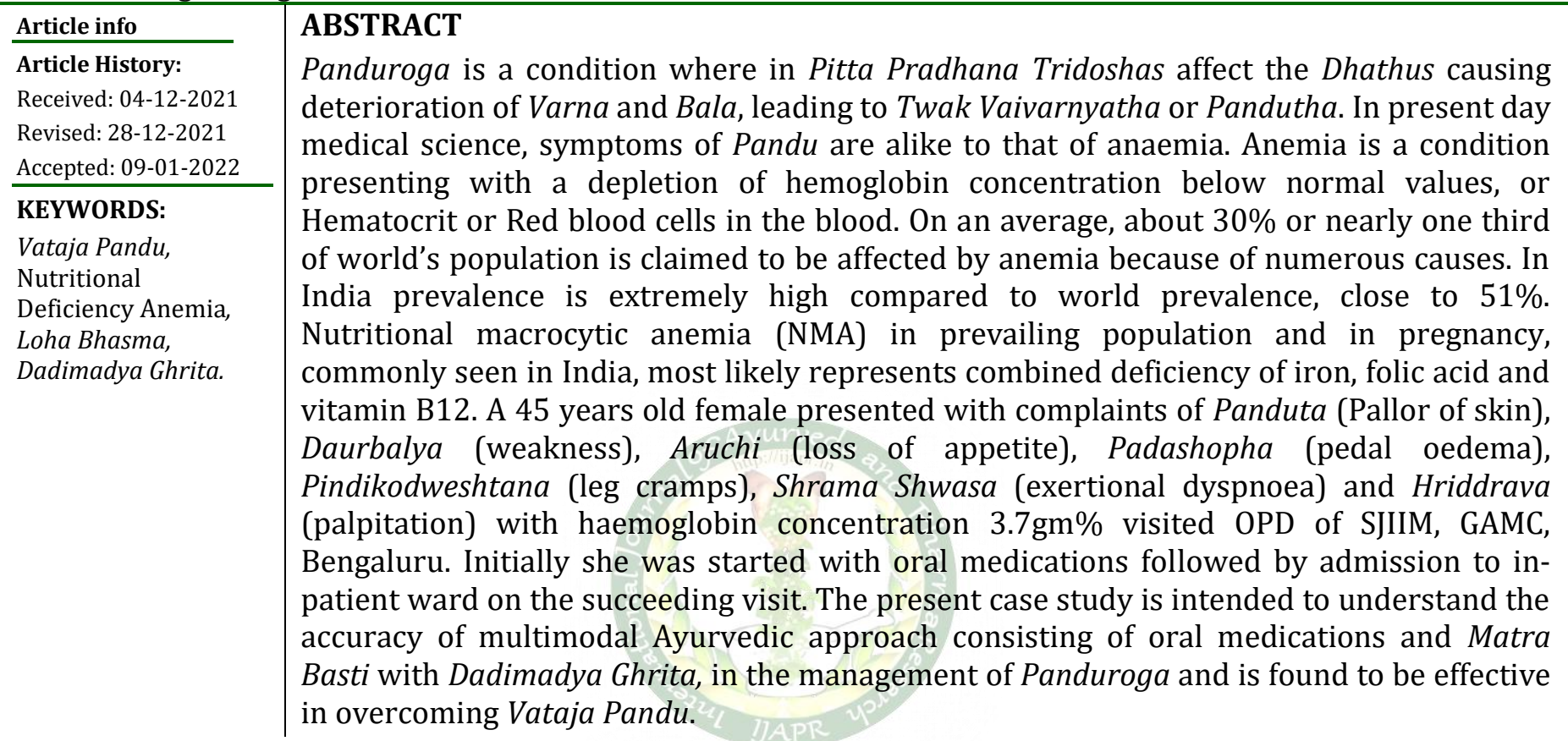

\section{INTRODUCTION}

Pandu can be understood as Pitta Dosha Pradhan Vyadhi associated with Rasa and Rakta Dhatu (lymph and blood tissue). Bhrajaka Pitta is responsible for the normal Varna of Twak (skin). The changing lifestyle of human being by means of Ahara and Vihara (diet and lifestyle) plays an important role in the manifestation of Pandu. Irregular/faulty Pitta Prakopaka dietary habits and lifestyle like Amla, Lavana, Katu Rasa Atisevana, Kshara, Ushna, Tisksna, Ruksha Ahara Atisevana, impairs the digestion, leading to Mandagni. Pitta Dosha further gets aggravated. Aggravation of Pitta causes vitiation of Rasa DhatuGauravata and Shaithilyata in Dhatu, and Bala, Varna, Sneha of Twak gets affected.

\begin{tabular}{|l|l|}
\hline \multicolumn{3}{|c|}{ Access this article online } \\
\hline Quick Response Code & \\
\hline & $\begin{array}{l}\text { https://doi.org/10.47070/ijapr.v10i1.1617 } \\
\text { Published by Mahadev Publications (Regd.) } \\
\text { Publication licensed under a Creative } \\
\text { Commons Attribution-NonCommercial- } \\
\text { ShareAlike 4.0 International (CC BY-NC-SA 4.0) }\end{array}$ \\
\hline
\end{tabular}

There is impaired Prasada Bhaga of Rasa Dhatu which leads to depletion in quality of Uttarottara dhatus, especially Rakta Dhatu.

Symptoms of Panduroga are, Karna Kshveda (tinnitus), Ajeerna (loss of digestive power), Daurbalya (Debility), Sadana, (malaise) Annadvesha (aversion to food), Shrama (exhaustion), Ruk (pain) in whole body are also seen. Vataja Pandu in specific is characterized by Krishna-pandutvam (pale discoloration of skin) and Ruksha Angata (dryness of skin). Its other symptoms are Angamarda (malaise), Ruja (ache), Toda (pricking pain), Kampa (tremor), Parshwa Ruja (pain in flanks), Shiroruja (headache); Varcha shosha (dried feces), Asya Vairasya (distaste in the mouth); Shopha (swelling), Anaha (gaseous distention of the abdomen) and Balakshaya (weakness) ${ }^{[1]}$. The treatment principle of Pandu Roga comprises both Shamana and Shodhana. In Bahudoshavastha Teekshna Shodhana is indicated. In Alpa and Madhyama Dosha avastha Shamana is ideal. Vataja Pandu Lakshanas can be specifically correlated to Nutritional Deficiency Anemia. Anemia refers to a 
condition presenting with a depletion of hemoglobin concentration below normal values, or Hematocrit or Red blood cells in the blood. Any of those three measures (Hemoglobin, Hematocrit, or number of red cells) may be used to for the diagnosis of anemia, however the blood hemoglobin level is usually most popular, thanks to its of its accuracy and reliability.

In present scenario according to $\mathrm{WHO}$, anaemia is very common in general population and around 2 billion people are suffering from anaemia across the world, which corresponds to $24.8 \%$ of the population[2]. In India prevalence is very high as compared to world prevalence which is approximately $51 \%$. In majority of the cases, anemia is caused by multiple factors- Iron deficiency, Vit B12 deficiency, folic acid deficiency and so on.

- Deficiency of Iron-manifested by microcytic hypochromic anemia with hyper cellular bone marrow. ${ }^{[3,4]}$

- Deficiency of folic acid and/or vitamin B12manifested by macrocytic anemia and a hyper cellular bone marrow with megaloblast, giant cells, metamyelocyte and abnormal megakaryocyte.

- Nutritional Macrocytic Anemia (NMA) which is the most common cause of anemia in India in general population and in pregnancy ${ }^{[5]}$, probably represents combined deficiency of iron, folic acid and vitamin B12 [6,7,8,9].

\section{Case Report}

A 45 years old female patient, Tailor by occupation visited the Outpatient Department of Panchakarma, SJIIM, GAMC, Bengaluru during the month of August 2021 presenting with symptoms of loss of appetite, nausea, excessive tiredness, muscle cramps, breathlessness on exertion, swelling of bilateral feet and palpitation since around 4 months. The patient was apparently normal before 4 months. Since then, she gradually experienced excessive tiredness after returning from work. She started developing muscle cramps and shortness of breath on doing minimum physical activities which worsened day by day. Since 2 months she complains of bilateral pedal edema. Additionally, she also complains of loss of appetite and palpitation. Past history revealed that she is not a known case of DM, HTN or any Thyroid Dysfunction. No members in family have similar complaints. Menstrual history is scanty and irregular. She belongs to lower middle class socio economic community and was cooperative. Her bowel habits were irregular and constipated, frequency of urine was 4-5 times/day and once at night, sleep was moderate. She used to control the urge of defecation and micturition regularly since about 20 years due to nature of her work. She was habituated to skipping afternoon meals and occasionally breakfast as well. Diet pattern was mixed with frequent use of dried fish.
Her weight is $40 \mathrm{~kg}$ with a height of $150 \mathrm{~cm}$ and BMI of 17.77. Patient had already consulted many doctors, where she was diagnosed with anemia with Haemoglobin levels of $3.7 \mathrm{gm} \%$. She had taken oral medicines for 2 months but had not found much relief. She was suggested for blood transfusion but was unwilling for the same. Ashta vidha Pariksha, Dashavidha Pariksha, general physical examination and systemic examination was done as mentioned in Table 1, Table 2, Table 3, Table 4 and Table 5 . Peripheral blood smear revealed Macrocytic hypochromic anemia. Considering the symptoms and lab investigations, patient was diagnosed with Vataja Pandu. Reg details - OPD No 22816, IPD No 541

Table 1: General Physical Examination

\begin{tabular}{|l|l|}
\hline Appearance & Ill look \\
\hline Consciousness & Alert \\
\hline Built & Hyposthenic \\
\hline Gait & Reduced Mobility \\
\hline Pallor & Present \\
\hline Icterus & Absent \\
\hline Clubbing & Absent \\
\hline Cyanosis & Absent \\
\hline Lymphadenopathy & No palpable lymph nodes \\
\hline Edema & Pedal edema \\
\hline
\end{tabular}

Table 2: Systemic Examination

\begin{tabular}{|l|l|}
\hline CNS & $\begin{array}{l}\text { Higher Mental Functions - Intact, } \\
\text { Orientation to time, place, person - intact, } \\
\text { Motor and sensory system- intact }\end{array}$ \\
\hline RS & $\begin{array}{l}\text { Trachea centrally placed, Chest bilaterally } \\
\text { symmetrical, Air entry bilaterally equal, } \\
\text { NVBS heard }\end{array}$ \\
\hline CVS & S1S2 heard, tachycardia + \\
\hline GIT & $\begin{array}{l}\text { Tongue- Pale, smooth texture, no dental } \\
\text { caries, P/A - soft, no palpable mass }\end{array}$ \\
\hline
\end{tabular}

Table 3: Vitals

\begin{tabular}{|l|l|}
\hline Pulse & $98 \mathrm{bpm}$ \\
\hline RR & $19 / \mathrm{min}$ \\
\hline BP & $110 / 70 \mathrm{~mm} \mathrm{Hg}$ \\
\hline Temp & $98.4 \mathrm{~F}$ \\
\hline
\end{tabular}

Table 4: Ashtasthana Pariksha

\begin{tabular}{|l|l|}
\hline Nadi & Vegavati \\
\hline Mutra & Ishat Peeta Varna \\
\hline Mala & Baddha, Shushka \\
\hline Jihwa & Pandu varna, Lipta \\
\hline Shabda & Deena \\
\hline Sparsha & Sheeta Sparsha \\
\hline Druk & Pakruta \\
\hline Akriti & Krusha \\
\hline
\end{tabular}


Int. J. Ayur. Pharma Research, 2022;10(1):32-39

Table 5: Dashavidha Pariksha

\begin{tabular}{|l|l|}
\hline Prakriti & Vata - Pittaja \\
\hline Vikriti & Pitta Pradhana Tridosha \\
\hline Sara & Madhyama \\
\hline Samhanana & Madhyama \\
\hline Satmya & Madhyama \\
\hline Satva & Pravara \\
\hline Ahara Shakti & $\begin{array}{l}\text { Abhyavaharana Shakti - Avara, } \\
\text { Jarana Shakti - Avara }\end{array}$ \\
\hline Vyayama Shakti & Avara \\
\hline Pramana & Madhyama \\
\hline Vaya & Madhyama \\
\hline
\end{tabular}

\section{Grading of Symptoms}

For the purpose of statistical assessment of results some grades and grade points considering the severity of different clinical features have been used as mentioned below in Table 6 and Table 13.

Table 6: Pandutha

Pandutha present in Nayana, Twak, Jihwa, Mootra \& Pureesha

\begin{tabular}{|l|l|}
\hline Not present & 0 \\
\hline Present in any one site & 1 \\
\hline Present in 2 or 3 sites & 2 \\
\hline Present in 4 to 6 sites & 3 \\
\hline
\end{tabular}

Table 7: Pindikodweshtana

\begin{tabular}{|l|l|}
\hline Not present & 0 \\
\hline Mild leg cramps only at night & 1 \\
\hline $\begin{array}{l}\text { Leg cramps present in night or on } \\
\text { exertion, requiring medical aid }\end{array}$ & 2 \\
\hline Leg cramps present throughout the day & 3 \\
\hline
\end{tabular}

Table 8: Shwasa

\begin{tabular}{|l|l|}
\hline Not present & 0 \\
\hline Shwasa on heavy work & 1 \\
\hline Shwasa on moderate work & 2 \\
\hline Shwasa on light work & 3 \\
\hline
\end{tabular}

Table 9: Agnisada

\begin{tabular}{|l|l|}
\hline Not present & 0 \\
\hline Present, hungry dislike food & 1 \\
\hline Present, doesn't hamper daily activity & 2 \\
\hline Present, hamper daily activity & 3 \\
\hline
\end{tabular}

Table 10: Daurbalya

\begin{tabular}{|l|l|}
\hline Not present & 0 \\
\hline $\begin{array}{l}\text { Daurbalya present, routines not } \\
\text { hampered }\end{array}$ & 1 \\
\hline Daurbalya present, routines hampered & 2 \\
\hline $\begin{array}{l}\text { Daurbalya always present, routines } \\
\text { hampered }\end{array}$ & 3 \\
\hline
\end{tabular}

Table 11: Aruchi

\begin{tabular}{|l|l|}
\hline Absent & 0 \\
\hline Occassional & 1 \\
\hline Intermittent & 2 \\
\hline Present always & 3 \\
\hline
\end{tabular}

Table 12: Hridrava

\begin{tabular}{|l|l|}
\hline No Palpitation & 0 \\
\hline Palpitation on Unaccustomed activity & 1 \\
\hline Palpitation on accustomed activity & 2 \\
\hline Palpitation at rest & 3 \\
\hline
\end{tabular}

Table 13: Arohanayasa

\begin{tabular}{|l|l|}
\hline Absent & 0 \\
\hline Stepping up to $>20$ steps & 1 \\
\hline Between $10-20$ steps & 2 \\
\hline Less than 10 steps & 3 \\
\hline
\end{tabular}

\section{Treatment plan}

Patient was started with oral medications initially for a period of 15 days - with Kamadugha Rasa 1TID before food, Punarnava Mandoora 2TID after food, Syr.4Blud $15 \mathrm{ml}$ BD after food. There was improvement in haemoglobin level from $3.7 \mathrm{gm} \%$ to 4.2 gm $\%$ during this period. On her next visit, she was advised admission to in-patient ward. Arogyavardhini Vati 1TID after food, Punarnava Mandoora 2TID after food, Kamadugha Rasa 1TID before food was given for 7 days. During this period, there was complete remission of pedal edema, improvement in appetite and relief from nausea completely. Dhatri Loha 2TID was added with the above medicines for a period of 7 days more. Hemoglobin level was found to be $4.7 \mathrm{gm} \%$ after this period. After assessing patient condition, Sarvanga abhyanga with Ashwagandha Balalakshadi Taila followed by Mridu sweda was advised for 7 days. Patient found relief in generalized weakness and muscle cramps. Next, Matra Basti with Dadimadya Ghrita $30 \mathrm{ml}$ with $1 \mathrm{gm}$ Loha Bhasma, 5gm Shatapushpa churna, 1gm Saindhava Lavana was administered for a period of 14 days. Retention time of Basti dravya progressively increased from 3 hours to 18 hours by the end of 14 days. Hemoglobin levels were assessed and were found to be $6.2 \mathrm{gm} \%$. She was now able to walk freely without breathlessness, there was improved appetite, bowels were regular and interest in daily activities. The treatment was further continued for 7 days and the patient was discharged. On discharge, she was advised with Dhatri Loha 2TID after food, Punarnava Mandoora 2BD after food, Arogyavardhini Vati 1TID after food, Syr. 4Blud 15ml after food, Dadimadya Ghrita $10 \mathrm{ml}$ BD before food for a period of 1 month, along with advise on PathyaApathya. Hemoglobin levels was tested to be $8.8 \mathrm{gm} \%$. The same treatment was continued for a period of 25 days and presently the haemoglobin levels are at $10.2 \mathrm{gm} \%$. Her weight has also increased from initial $40 \mathrm{~kg}$ to present $45 \mathrm{~kg}$ with BMI from 17.77 to present 20. Patient did not complain of any sort of discomfort 
Swathi Bhat, Ananta S Desai. Effectiveness of Multimodal Ayurvedic Treatment in Vataja Pandu w.s.r Nutritional Deficiency Anemia during and after the drug administration. None of the or constipation.

treatment modalities caused any gastric disturbances

Table 14: Treatment Given

\begin{tabular}{|c|c|c|}
\hline Period & Treatment Given & Results \\
\hline $\begin{array}{l}17 \text { Aug } 2021- \\
31 \text { Aug } 2021\end{array}$ & $\begin{array}{l}\text { Kamadugha Rasa 1TID B/F, Punarnava Mandoora } \\
\text { 2TID A/F, Syr. 4Blud } 15 \text { ml BD A/F }\end{array}$ & $\begin{array}{l}\text { Increase in hemoglobin level from } 3.7 \mathrm{gm} \% \\
\text { to } 4.2 \mathrm{gm} \%\end{array}$ \\
\hline \begin{tabular}{|c|} 
01 Sep $2021-$ \\
07 Sep 2021 \\
\end{tabular} & $\begin{array}{l}\text { Arogyavardhini Vati 1TID A/F, Punarnava } \\
\text { Mandoora 2TID A/F, Kamadugha Rasa 1TID B/F }\end{array}$ & \multirow{2}{*}{$\begin{array}{l}\text { Complete remission of pedal edema, } \\
\text { improvement in appetite and relief from } \\
\text { nausea } \\
\text { Increase in haemoglobin level from } \\
4.2 \mathrm{gm} \% \text { to } 4.7 \mathrm{gm} \%\end{array}$} \\
\hline $\begin{array}{c}\text { 08 Sep } 2021- \\
15 \text { Sep } 2021\end{array}$ & $\begin{array}{l}\text { Arogyavardhini Vati 1TID A/F, Punarnava } \\
\text { Mandoora 2TID A/F, Kamadugha Rasa 1TID B/F, } \\
\text { Dhatri Loha 2TID A/F }\end{array}$ & \\
\hline \begin{tabular}{|l|}
16 Sep $2021-$ \\
21 Sep 2021 \\
\end{tabular} & \begin{tabular}{|l} 
Sarvanga abhyanga with Ashwagandha \\
Balalakshadi Taila followed by Mridu sweda
\end{tabular} & $\begin{array}{l}\text { Relief in generalized weakness and muscle } \\
\text { cramps, bowels regular }\end{array}$ \\
\hline $\begin{array}{l}22 \text { Sep } 2021- \\
13 \text { Oct } 2021\end{array}$ & $\begin{array}{l}\text { Sarvanga abhyanga with Ashwagandha } \\
\text { Balalakshadi Taila followed by Mridu sweda } \\
\text { Matra Basti with Dadimadya Ghrita } 30 \text { ml with } \\
\text { 1gm Loha Bhasma, } 5 \text { gm Shatapushpa churna, } \\
\text { 1gm Saindhava Lavana }\end{array}$ & $\begin{array}{l}\text { Increase in haemoglobin level from } \\
4.7 \mathrm{gm} \% \text { to } 6.2 \mathrm{gm} \% \text {. } \\
\text { Improvement in retention period of Basti } \\
\text { dravya from } 3 \mathrm{hrs} \text { to } 18 \mathrm{hrs} \\
\text { Regular bowels with soft consistency, } \\
\text { reduced weakness }\end{array}$ \\
\hline $\begin{array}{l}14 \text { Oct } 2021- \\
16 \text { Nov } 2021\end{array}$ & $\begin{array}{l}\text { Dhatri Loha 2TID A/F, Punarnava Mandoora 2BD } \\
\text { A/F, Arogyavardhini Vati 1TID A/F, Syr. 4Blud } \\
\text { 15ml A/F, Dadimadya Ghrita 20ml BD B/F }\end{array}$ & $\begin{array}{l}\text { Increase in haemoglobin level from } \\
6.2 \mathrm{gm} \% \text { to } 8.8 \mathrm{gm} \%\end{array}$ \\
\hline $\begin{array}{l}17 \text { Nov } 2021- \\
14 \text { Dec } 2021\end{array}$ & $\begin{array}{l}\text { Dhatri Loha 2TID A/F, Arogyavardhini Vati 1TID } \\
\text { A/F, Syr. 4Blud 15ml A/F, Dadimadya Ghrita } \\
\text { 20ml BD B/F }\end{array}$ & $\begin{array}{l}\text { Increase in haemoglobin level from } \\
8.8 \mathrm{gm} \% \text { to } 10.2 \mathrm{gm} \% \\
\text { Increase in weight from initial } 40 \mathrm{~kg} \text { to } \\
\text { present } 45 \mathrm{~kg} \text { with BMI from } 17.77 \text { to } \\
\text { present } 20 \text {. }\end{array}$ \\
\hline
\end{tabular}

Table 15: Assessment of subjective parameters before, during and after treatment with scores

\begin{tabular}{|l|c|c|c|c|c|c|}
\hline Parameters & 17 Aug 21 & 15 Sep 21 & 13 0ct 21 & 16 Nov 21 & 14 Dec 21 & Relief in \% \\
\hline Panduta & 2 & 2 & 1 & 1 & 0 & 100 \\
\hline Pindikodweshtana & 3 & 3 & 2 & 1 & 0 & 100 \\
\hline Shwasa & 3 & 3 & 2 & 1 & 1 & 75 \\
\hline Agnisada & 3 & 2 & 1 & 0 & 0 & 100 \\
\hline Daurbalya & 3 & 2 & 1 & 0 & 0 & 100 \\
\hline Aruchi & 3 & 2 & 0 & 0 & 0 & 100 \\
\hline Hridrava & 2 & 1 & 1 & 0 & 0 & 100 \\
\hline Arohanayasa & 3 & 3 & 2 & 1 & 1 & 75 \\
\hline Total Score out of 24 & 22 & 18 & 10 & 4 & 2 & 90.9 \\
\hline
\end{tabular}

Laboratory Assessment

The following laboratory findings had been assessed before, during, and after treatment, as mentioned in table 16:

1) Total RBC count, 2) blood hemoglobin level, 3) HCT, 4) MCV, 5) MCHC, 6) MCH, 7) RDW

Table 16: Assessment of different haematological parameters before, during and after treatment

\begin{tabular}{|l|c|c|c|c|c|}
\hline Parameters & 17 Aug 21 & 15 Sep 21 & 13 0ct 21 & 16 Nov 21 & 14 Dec 21 \\
\hline Total RBC Count in $10^{\wedge} 6 / \mathrm{uL}$ & 0.85 & 1.11 & 1.50 & 2.6 & 3.4 \\
\hline Haemoglobin & $3.7 \mathrm{gm} \%$ & $4.7 \mathrm{gm} \%$ & $6.2 \mathrm{gm} \%$ & $8.8 \mathrm{gm} \%$ & $10.2 \mathrm{gm} \%$ \\
\hline HCT & $10.1 \%$ & $12.2 \%$ & $15.3 \%$ & $26.4 \%$ & $30.6 \%$ \\
\hline MCV & $118.8 \mathrm{fL}$ & $110.1 \mathrm{fL}$ & $102.0 \mathrm{fL}$ & $101.5 \mathrm{fL}$ & $90.0 \mathrm{fL}$ \\
\hline MCHC & $36.6 \mathrm{gm} / \mathrm{dL}$ & $38.5 \mathrm{gm} / \mathrm{dL}$ & $40.5 \mathrm{gm} / \mathrm{dL}$ & $33.3 \mathrm{gm} / \mathrm{dL}$ & $33.3 \mathrm{gm} / \mathrm{dL}$ \\
\hline MCH & $43.5 \mathrm{pg}$ & $42.3 \mathrm{pg}$ & $41.3 \mathrm{pg}$ & $33.8 \mathrm{pg}$ & $30.0 \mathrm{pg}$ \\
\hline RDW & $12.9 \%$ & $11.7 \%$ & $13 \%$ & $11.7 \%$ & $12.2 \%$ \\
\hline
\end{tabular}




\section{DISCUSSION}

Though both the genders are susceptible to the affliction of anemia, it is more common in females. Women of reproductive age i.e., during 15-49 years are particularly at increased risk of nutritional deficiency and, therefore, anemia, compared to men, due to physiological changes such as menstruation (blood loss pathway), pregnancy (inadequate production pathway due to increased demand) and bleeding in childbirth, is more prevalent in females. Additionally, unequal household food allocation can make women vulnerable to anemia as they might not have access to nutrition-rich foods ${ }^{[10]}$. Families of poor income group are unable to afford proper diet and due to improper and imbalanced diet, women of those families may easily suffer from nutritional deficiencies[11]. In accordance to Ayurveda, inadequate functioning of Agni is the primary reason behind all ailments. Patient in this study suffered from Mandagni and had Krura Koshta. Consumption of inadequate nutrition due to Mandagni leads to inanition, which worsens the disease. Krura Koshtha having dominance of Vata results in improper digestion, and insufficient absorption, furthermore deteriorates the condition of malnutrition.

After 3 months of intervention with Ayurvedic drugs there was marked improvement observed in the clinical features as well in the haemoglobin levels. Matra basti is always useful for persons emaciated by excess activities and for person who are weak and afflicted with Vatika disorders. Matra Basti can be administered safely in any season. Throughout the course of this treatment, the patient is allowed to continue his routine diet and activities with none restrictions. Matra basti helps in improving physical strength and helps in easy evacuation of stool. It improves nourishment and cures diseases caused by aggravated vata ${ }^{12}$. After administration of Matra Basti with Dadimadya Ghrita, relatively quicker enhancements were observed in the clinical features such as pallor, anorexia, weakness, fatigue, irritability, etc and evident changes were also observed in haematological parameters, than compared to initial improvement with solely oral medications.

\section{Discussion on Treatment Adopted}

Dadimadya Ghrita: In Pandu, there's predominant derangement of Pitta Dosha. Dadima (Punica granatum Linn.) by virtue of Madhura (sweet) and Kashaya (astringent) Rasa acts as Pitta Shamana. Dhanyaka possesses Deepana (appetizer) and Pachana (carminative) properties alongside Chitraka acts as Agnimandyahara (cures weak digestion) that helps to disintegrate Dosha-dushya samurchana. Chitraka (Plumbago zeylanica) holds Tikshna, Laghu, Ruksha guna; Katu, Tikta rasa, Katu vipaka and Ushna veerya. Attributing to it, it alleviates Kapha-vata, and will increase Pitta. Since here it's processed with cow ghee, its Pitta vardhaka property is reduced. It enhances the secretions of mucus membrane of stomach and helps for digestion and absorption. Shunthi (Zingiber officinalis Roscoe) has Laghu and Snigdha guna; Katu rasa; Madhura vipaka and Ushna veerya. Its use has been described in Pandu by Bhavaprakasha. It is Deepana and Pachana, so acts as Amapachaka (digests $a m a$ ). It functions as a good blood purifier, improves circulatory system and cardio vascular system. Pippali (Piper longum Linn.) possesses Laghu, Snigdha and Tikshna guna, Katu rasa, Madhura vipaka and Anushna sheeta veerya. Therefore it balances Kapha-vata. It aids in resurrection of Rakta dhatu. As explained in Charaka Samhita, Ghritha is possesses the property of PittaAnilahara, promotes Rasa dhathu, Shukra dhathu and Ojas. It is Nirvapanam (cooling), Mrdukaram (softening) and Swaravarna prasaadanam (clarity of voice and complexion). Ghritha is mainly advisable for those who are Ksheena and Abala. Ghritha is taken into account as Uttama among 4 varieties of Sneha by Charaka, because of its quality of effective assimilation with the properties of other drugs with which it is prepared with (Samskaarasya Anuvarthanaath). Among the various modalities of treatments of Pandu Roga laid down in Ayurvedic classics, use of Ghrita Yogas is initially mentioned, hinting towards the role of Ghrita in correcting the impaired metabolic functions and thereby improving absorption and further assimilation. Thus as a whole this recipe disintegrates Dosha-dushya Samurchana and helps to revive health.

1. Loha bhasma is attributed with quality of Deepana, Ruchikara and Rakta vardhana. It cures excess of Pitta with its Sheeta virya and Kashaya-Tikta rasa. It restores the functional activities of liver and spleen. By virtue of Dravya samanyata (Samanya Vishesh Siddhant), it increases Hemoglobin level in the blood.

2. Abhyanga improves blood circulation at local site, in conjunction with stimulating the neurons to give a tranquillizing and soothing result. It is performed in concentric fashion over the joints to enhance the lymphatic and venous emptying since large number of lymph nodes are situated within the joint spaces in conjunction with collateral blood vessels. In addition, Abhyanga enhances the local blood flow, transferring increased nutrients and oxygenated blood, that relieves exhaustion and muscle fatigue. Enhancement of blood flow conjointly assists the elimination of toxins and unwanted products from the tissue. Wholly, the outcome of Abhyanga is directly or indirectly associated with the stimulation of involuntary nervous system and central nervous system[13]. 
3. Kamadugha Rasa contains Swarasa of Dhatri, Ghritabharjita Gairika which are having Deepana, Pachana, Kaphavatahara, Pittashamana and Balya properties, that cause Agnideepti and in turn leads to proper metabolism as well as formation of proper Rasa raktadi Dhatus. Gairika $\left(\mathrm{Fe}_{2} \mathrm{O}_{3}\right)$ consists of $70 \%$ of Iron. Attributing to its Tiktarasa and Madhurarasa it helps in Agnideepana and results in appropriate metabolism and Dhatu Poshana (anabolism). Thus, the cumulative effects of the drugs lead to correction of metabolism, iron absorption, improved blood formation and correction of disease.

4. Dhatri Loha contains Shunti, Maricha and Pippali which are Deepana, Pachana, Kaphavatahara and Amadoshahara as well as Srotoshodhaka properties that cause Agnideepti and Amapachana in turn leads to proper metabolism as well as formation of proper rasa Raktadidhatus. Amalaki, enhances the iron absorption. Amalaki (Emblica officinalis) is considered to be the richest source of Vitamin $\mathrm{C}$ that aids in absorption of iron. Vitamin $\mathrm{C}$ helps in reduction of ferric iron to ferrous iron that remains in soluble form even in neutral $\mathrm{pH}$ and is absorbed better. Amalaki increases the manufacturing of RBCs and increases immunity in the body. Nisha is Pitta virechaka and Varnya, thus corrects Pitta and Rakta. Loha Bhasma, has Deepana, Balya, Rasayana and Raktavardhaka properties that lead to proper metabolism and Dhatuposhana. Thus, the conjoint effect of the components of Dhatri Loha, results in enhanced metabolism, better iron absorption, increased production of RBCs and relief from the condition[14].

5. Large number of ingredients in Punarnava Mandoora like, Trikatu, Chitraka, Triphala, Vidanga and Pippalimula are having the properties of improving appetite, promoting digestion and carminative properties. Some ingredients act as purgative which help in relieving constipation like Trivrit, Haritaki and Danti and assist in Nitya Virechana (removing the excess Pitta on a daily basis). Various Acharyas consider Punarnava, Haridra, Pippali, Amalaki, and Trivrit as Vyadhipratyanika Dravyas for Pandu. Several other ingredients like Danti, Amalaki, Punarnava, Pippali, Kushtha and Daruharidra are known to possess immunomodulating and antioxidant effects. Thereby they are likely to be beneficial in geriatric anemia as well[15]. Since Punarnava mandura is comprised of Gomutra (Cow's urine) it also acts as Rasayana by virtue of its antioxidant property. Its use is attributed for immunomodulation since ages. Erythropoietin hormone is found in Cow's urine which accounts for its extensive mentioning in the treatment of Pandu in Samhitas. Iron component in
Cow's urine helps to maintain a balance and further production of RBCs and Haemoglobin ${ }^{16}$.

6. Arogyavardhini vati comprises Parada, Gandhaka, Abhraka, Loha, Tamra etc along with large amount of Katuki, which is extensively used herb in disorders of liver. It contains Haritaki (Terminalia chebula) which has Kashayarasa (astringent) and does Rechana (laxative in nature). Bibhitaki (Terminalia belerica) is a laxative as well. It is used in digestive disorders and is a time tested anthelmintic. Amalaki- (Emblica officinalis) has high concentration of antioxidants, and is hepato protective with immuno modulator qualities. Shuddh shilajit is effective for revival of exuberance. Its action is similar to that of nectar; having antioxidant properties and thereby prolongs the aging process. Guggulu (Commiphora mukul), is useful in bringing down cholesterol by transforming it into bile. It is beneficial for elimination of unwanted fats and stabilizing the cholesterol levels. Chitraka (Plumbago zeylancia) is useful in conditions of indigestion, loss of appetite, piles, colitis, worms and several liver disorders. Arogyavardhini vati has Rakta-pitta shodhaka, yakrut-uttejaka property. It does the Shoshan (assimilation) of excess Snigdha dravyas (unctuous substances) present in the body and does the Raktavardhana (improves quality of blood). Thus, the contents of Arogyavardhani Vati like Triphala and Katuki (Picrorhiza kurroia), with Bhasma (metallic/mineral preparation)and Kajjali (mercury sulphur bond) becomes capable for detoxifying due to Sara Guna by removing obstruction in Srotas (channels). Based on this fact the drug helps in breaking the pathogenesis of Pandu Roga (Anaemia). Yakrit being the Moola for Raktavaha srotas, when gets stimulated, might help in promoting improved quality and quantity of Rakta Dhatu.

7. Effectiveness of Haritaki, Mandoora Bhasma, and Loha Bhasma to increase blood hemoglobin level has been proved scientifically by previous research studies $[17,18,19]$.

8. Blud Syrup contains Seva (Pyrus malus), Punarnava (Boerrhavia diffusa), Ashwagandha (Withania somnifera), and Yashtimadhu (Glycyrrhiza glabra) as main active ingredients along with Amalaki (Emblica officinalis), Vibhitaki (Terminalia belerica) and Shuddha Kaseesa. Kaseesa is indicated in Pandu, Agnimandya, Kashtartava, Shotha, Gudabhramsha, Rajorodha, Arsha, Yonivyapada and Shvitrakustha. Kasisa bhasma has definite haematinic effect and it leads to cytological and chromological changes in the blood[20]. 


\section{Discussion on Haematological Parameters}

1. Total RBC Count: Bone marrow produces about half a litre of blood every week in a normal healthy adult. On being stimulated to peak activity along with adequate nutrition, the marrow can recoup for the loss of several pints of blood per week. The marrow is capable of increasing its RBC production up to eight times the usual rate[21]. Hence, it can be seen that the amount of RBCs have increased gradually by the correction of absorption and improved nutritional supplementation in the form of oral medicines as well Dadimadya Ghrita Matra Basti.

2. Haemoglobin levels: Hemoglobin $(\mathrm{Hb})$ is the most abundant protein in erythrocytes, whose function is to transport oxygen from the lungs to tissues. $1 \mathrm{gm} \%$ hemoglobin, when fully saturated, combines with $1.34 \mathrm{~mL}$ of oxygen, therefore, hemoglobin concentration is an index of oxygen carrying capacity of blood. Anemia may result from any condition that leads to depletion of concentration of functional haemoglobin or in destruction of RBCs. With effective supplementation, it can be observed that there is improved erythropoiesis and proper maturation of RBC resulting in increase of Haemoglobin levels.

3. Haematocrit: The hematocrit measures the volume of red blood cells compared to the total blood volume (red blood cells and plasma). The average haematocrit value in men is 40 to $54 \%$; and in women it is 36 to $48 \%$. Lower than normal haematocrit values can be a result of anemia, nutritional deficiencies, blood loss or active infection in the body. It can be observed that there is eventual increase of haematocrit values suggesting that there is increase in the number of red blood cells.

4. MCV: When the MCV is below the reference interval it is called microcytosis; within the reference interval, normocytosis; and above the reference interval, macrocytosis. The initial blood picture depicted macrocytosis indicative of nutritional deficiency anemia while gradually it was observed that the MCV values came down to normal range, suggesting the correction of Macrocytosis, indirectly implicating that the deficiency has been overcome, through correction of Agni, leading to appropriate absorption as well by supplementation through various formulations like Dhatri Loha, Dadimadya Ghrita etc.

5. MCHC: Hypochromia is a condition where MCHC levels are below the normal reference interval while it is considered as Normochromia if the MCHC value lies within the reference interval. Hemoglobin production is regulated by the accumulation of hemoglobin to a concentration of approximately
$33 \%$, at which point it remains soluble and with optimum function. MCHC can be raised in conditions of dehydration and in macrocytic anemia. It can be seen that there is gradual reduction of MCHC to normal ranges in the later reports, suggesting the correction of macrocytes thereby indicating appropriate maturation of RBC.

6. MCH: MCH stands for mean corpuscular hemoglobin. It refers to the average amount of hemoglobin present in a single RBC. The reference range for $\mathrm{MCH}$ lies between 27.5 and 33.2 picograms (pg). An $\mathrm{MCH}$ value above $33.2 \mathrm{pg}$ is regarded as high MCH. High MCH value can often be caused by anemia due to nutritional deficiency particularly of Vitamins and Folate. There is gradual decrease of $\mathrm{MCH}$ values to normal range during the course of treatment, pointing towards correction of nutritional deficiency in the patient.

7. RDW: It is a statistical calculation of the variability of the size of the red blood cells. An increase in RDW suggests increased variation in size of red cell termed as anisocytosis. An RDW value which lies within the reference interval suggests no anisocytosis. A sudden raise in RDW can be observed after the administration of Matra Basti, indicating the probable increase in production of red blood cells leading to a wide difference in the morphology as a large number of cells could be in the reticulocyte stage, undergoing maturation, after which there is constant increase in haemoglobin levels in the next two visits, and RDW range has come down to normal levels.

\section{CONCLUSION}

Clinical features of Vataja Pandu roga (Nutritional Deficiency Anemia) are mainly due to quantitative and qualitative reduction of Hemoglobin and less oxygen supply in the tissues. With the aid of Ayurvedic interventions, when there is increase in haemoglobin levels, body tissues get adequate oxygen, body metabolism improves, and ultimately relief in clinical symptoms is observed. By apt diagnosis and correction of root cause of the disease, it can be clearly seen that there has been significant improvement in subjective parameters as well as haematological components. The present case study signifies the role of Ayurvedic multimodal treatment approach in successfully overcoming the condition without any evident side effects. Hence it can be concluded that principle of treatment explained in Ayurveda can be used to effectively treat Nutritional Deficiency Anemia.

Since this is a single case study, further study is needed to observe the effect of above treatment modalities on more number of patients and for longer duration to remark other benefits. 


\section{REFERENCES}

1. Charaka Samhita of Agnivesha- elaborated by Caraka and Drdhabala with the Ayurveda Dipika commentary by Sri Cakrapanidatta edited by Vaidya Yadavji Trikramji Acharya reprint edition 2014 Varanasi Chaukhamba Surabharati Prakashan Chikitsa sthana $16^{\text {th }}$ chapter $18^{\text {th }}$ verse pp - 527

2. Dr. S. Sujan, Dr. Sunil P. Changle, Dr. Swapnil C. R., A critical review of Pandu Roga in children w.s.r. to iron deficiency anaemia, World journal of pharmaceutical and medical research, www.wjpmr.com, 2017, 3(9)

3. Kumar A. National nutritional anaemia control programme in India. Indian J Public Health. 1999; 43(1):3-5.

4. Gururaj N, Sivapathasundharam B, Sumathy N. Cytological findings in iron deficiency anemia. Indian J Dent Res. 2004; 15(4): 126-28.

5. Nutritional deficiency Das AK. 1st ed. Calcutta: Books and Allied (P) Ltd; 2000. Medical Physiology; p. 726

6. Carlo Brugnara. A Hematologic "Gold Standard" for Iron-deficient States. Clinical Chemistry. 2002; 48(7): 981-82.

7. Florence A, Joseph J.M, Steven H.Y. Megaloblastic Anemia and Other Causes of Macrocytosis. Clinical Medicine \& Research. 2006; 4(3): 236-41.

8. Antony AC. Megaloblastic anemia. In: Hoffman R, Benz EJ, Shattil SJ, Furie B, Cohen HJ, Silberstein LE, et al. (eds). Hematology. Basic principles and practice. 4th ed. Edinburgh: Churchill Livingstone; 2005:51956.

9. Yusufji D, Mathan VI, Baker SJ. Iron, folate and vitamin B12 nutrition in pregnancy: A study of 1000 women from southern India. Bull World Health Organ 1973; 48: 15-22.

10. Kinyoki, D., Osgood-Zimmerman, A.E., Bhattacharjee, N.V. et al. Anemia prevalence in women of reproductive age in low- and middle-income countries between 2000 and 2018. Nat Med 27, 1761-1782 (2021). https://doi.org/10.1038/s41591 -021-01498-0.

11. Girard, A. W., Self, J. L., McAuliffe, C. \& Olude, O. The effects of household food production strategies on the health and nutrition outcomes of women and young children: a systematic review. Paediatr. Perinat. Epidemiol. 26, 205-222 (2012).

12. Charaka Samhita of Agnivesha- elaborated by Caraka and Drdhabala with the Ayurveda Dipika commentary by Sri Cakrapanidatta edited by Vaidya Yadavji Trikramji Acharya reprint edition 2014 Varanasi Chaukhamba Surabharati Prakashan Siddhi sthana 4th chapter 52-54th verse pp - 701

13. Madhukar LS, Nivrutti BA, Bhatngar V, Bhatnagar S (2018) Physio-Anatomical Explanation of Abhyanga: An Ayurvedic Massage Technique for Healthy Life. J Tradit Med Clin Natur 7: 252. DOI: 10.4172/25734555.1000252

14. Ramadevi. G Et; Al: A Comparative Clinical Study On The Effect Of Kamadugh Rasa And Dhatri Lauha In Garbhini Pandu (Iron Deficiency Anaemia)

15. Pandya, M. G., \& Dave, A. R. (2014). A clinical study of Punarnava Mandoora in the management of Pandu Roga in old age (geriatric anemia). Ayu, 35(3), 252260. https://doi.org/10.4103/0974-8520.153735

16. Banga RK, Singhal LK, Chauhan RS. Cow urine and immunomodulation: An update on cowpathy. Int J Cow Sci. 2005; 1(2): 26-9

17. Kumath V. On Pandu Roga, MD thesis. P. G. Department of Dravyaguna, Government Ujjain, Madhya Pradesh: Autonomous Dhanvantari Ayurveda College and Hospital; 2006.

18. A Comprehensive Study of Haritaki with Special Reference to the Efficacy of Terminalia chebula Retz. /Agrawal N. P.G. Department of Kaumarbhritya. Varanasi: IMS, B.H.U; 2007.

19. Sarkar PK. I.P.G.T. \& R.A. Jamnagar: Gujrat Ayurveda University; 2005. A Comparative Pharmaceuticopharmaco-clinical study of Lauha Bhasma and Mandoora Bhasma w.s.r. to its Pandu-hara Effect, MD thesis.

20. Surinder Kumar, BMJ Ayurveda Medical College, Gadag, Karnataka; 2014. Pharmaceutico-Analytical Study of Kasisa Bhasma and its clinical efficacy in Pandu Roga WSR General Blood Picture.

21. Conley, C. Lockard and Schwartz, Robert S. (2020, October 24). blood. Encyclopedia Britannica. https://www.Britannica.com/science/bloodbiochemistry.

\section{Cite this article as:}

Swathi Bhat, Ananta S Desai. Effectiveness of Multimodal Ayurvedic Treatment in Vataja Pandu w.s.r Nutritional Deficiency Anemia - A Case Report. International Journal of Ayurveda and Pharma Research. 2022;10(1):32-39.

\section{https://doi.org/10.47070/ijapr.v10i1.1617}

Source of support: Nil, Conflict of interest: None Declared

Disclaimer: IJAPR is solely owned by Mahadev Publications - dedicated to publish quality research, while every effort has been taken to verify the accuracy of the content published in our Journal. IJAPR cannot accept any responsibility or liability for the articles content which are published. The views expressed in articles by our contributing authors are not necessarily those of IJAPR editor or editorial board members. 